\title{
ON THE PHENOMENA OF AGEING AND DEATH FROM THE PERSPECTIVE OF HUMANITIES (THE TABOO OF THE PHENOMENON OF DEATH FROM THE POINT OF VIEW OF NEW TASKS IN PEDAGOGICAL SCIENCES)
}

\section{Vlasta Cabanová}

"It seems that the more we penetrate into natural sciences, the more we are afraid of reality of death and we deny it" (Kübler-Ross, 1990)

\begin{abstract}
The birth and death are natural parts of human life. The arrival of a baby to this world is often vividly and widely discussed issue in the family, media, at school (it is directly included in school rituals, school books and textbooks); we often encounter colourful descriptions of various aspects of the baby's arrival to this world. On the other hand, the phenomena of the end of human life are depicted only in a symbolic way; in modern societies of the $21^{\text {st }}$ century, the topic of death is being tabooed to large extent. In the era of a considerable demographic trend, when a noticeable ageing of the Slovak population can be witnessed, it is necessary to pay close attention to the phenomena of ageing and death.
\end{abstract}

\section{Keywords}

ageing of the Slovak population, family upbringing, school education, loneliness, quality of life, positive ageing, understanding, preparation for death, pedagogical sciences, social pedagogy

\section{The ageing process as a taboo}

In terms of average life expectancy, the period of old age constitutes almost a third of life of a human being and the process of ageing constitutes more than half of life. This 
is a considerable period of time in human life; however, little attention is being paid to ageing and to the processes and conditions associated with it. One of the most serious reasons may be the notion of ageing as a period of disproportionately large losses: it is the period associated with the loss of strength, of physical and mental weakness, fatigue and chronic illness. In the era of European culture of the $21^{\text {st }}$ century, which puts emphasis on youth, senior citizens find themselves at the periphery of society. Austrian psychologist Maria Fürst observes that "[a]t a time when youth has become a myth, it is wrong to be old. Old age is a taboo" (Fürst, 1997, p. 153). Cimický and Sámková (2018) draw attention to the fact that even senior citizens themselves claim that they already feel that they have reached the limit moment when their incapability and the loss of physical strength are manifested. In fact, such a perception of ageing by the public, as though even confirmed by senior citizens themselves, is to a considerable degree situational. The fact that people from close surroundings gradually leave the environment of an ageing person (Matoušek et al., 2007) significantly contributes to the fact that a person withdraws into themselves and focuses more on themselves, which also includes the identification of various symptoms of diseases. Given various forms of seclusion, senior citizens have more time which is available and consequently, they also ponder about the meaning of life (Adler, 1998) and thoughts about the end of their life.

It can be stated that in a period of experimentation, adolescents "play" with the ideas of death and an adult person only reflects upon death only at times of a severe crisis of existence, in the period of ageing, the thoughts of the inevitable death are much more persuasive and can induce anxiety even when the situation concerns a completion of a fruitful life. With the senior citizens, the structure and extent of the individual system as well as the perception of one's own identity are permanently changing (Witte, 1989 in Nakonečný) from transient states, there is a resulting more depressed mood, hypochondriac anxiety, more intensive dissatisfaction, pessimism, and in certain cases, an exaggerated critical anger and an overt animosity towards the nearest surroundings (Cimický \& Sámková, 2018).

In addition, an unjustified questioning of their abilities on the basis of age contributes to deepening frustrations of senior citizens. There are a number of reasons for people (in Slovakia, problems with finding employment emerge after the age of fifty) for experiencing the feelings of being social outsiders, because in many professions, despite their vitality, enthusiasm and willingness to work, they are unemployable and permanently sidelined (IVO, 2012; Gabrižová, 2017). From the perspective of modern society, a stereotyped image has been established, which is misleading on the basis of physical signs (Nakonečný, 1999) and claims that "senior citizens are slow and weak" (Atkinson et al., 2003, p. 195). They are often discriminated against on the basis of age, especially when looking for a job and the access to health care also poses more complications (Barát, 2012). In addition to these stereotypes, the perception of young people presents a negative intergenerational attitude in the form of the most widespread prejudices which deepen the intergenerational divide (Cabanová, 2012). As a result, this powerful emotional drive has an immense impact on vulnerability of senior citizens. According to surveys, the handicap of finding employment based solely on age-i.e. "ageism" presents 
a frequent social prejudice and the international measurement provides the strongest reason for discrimination in Slovakia (Koval, 2001; Gabrižová, 2017), while the sources of ageism are primarily of social and cultural nature (Cabanová, 2012; Dončevová, 2017). Despite the fact that the Slovak Republic has joined several international declarations (2014), effective legislative measures against this social ill have not yet been adopted. Senior citizens feel rightfully frustrated and they experience significant and irreversible uncertainties (Matoušek, 1999). It is proven that if a senior citizen has a sufficient amount of time, well-being and peace to solve a problem, they are successful in most cases equally well as a young, often unsettled individual (Cimický \& Samková, 2018).

In a micro-view at the individual level, the ageing process is understood as the sum of qualitative changes in the structure and functions of human body that affect the increased vulnerability and decline of certain abilities and performance of the individual and they culminate at the terminal stage of death (Langmeier \& Krejčirrová, 2006). Ageing involves a number of changes and it is a multidimensional process that presents the dimensions of natural transformation of personality, which is accompanied with the loss of performance, the scope of functions, various forms of declines and certain limitations. For centuries, the idea of ageing in this form has been considered a standard and a natural process.

Senior citizens are able to compensate their deficits, especially in terms of motor abilities, by wisdom and with the ability to evaluate experience more effectively. In the holistic perception of the issue, on the basis of previous experience, in the process of solving the problem, senior citizens acquire situational understanding much more quickly, rationalize and evaluate divergent solutions until choosing an optimal resolution. Slovak folk wisdom states that older people walk worse but they think better. This observation is evidenced by wisdom and performance of statesmen and politicians who entered public policy after the age of seventy, or whose performance culminated at this age, as well as scientists who brought to mankind significant discoveries, patents and inventions.

Therefore, the actual onset of the ageing processes is not precisely defined in time and it is genetically determined to certain extent (Šmarda et al., 2017). However, at the same time, it is closely related to external conditions of life of a particular person and their lifestyle that can take the role of initiators that either accelerate or deaccelerate the ageing processes. This is largely due to the fact that there are 40-year-old "grandpas" and "80-year-young men" (physically fit athletes and intellectual inventors, reformers, diplomats, etc.). Older age is not a hundred percent guarantee of wisdom and vice versa, youth is a hundred percent guarantee of ideas and innovation. On the basis of this reason, retirement can present a negative aspect for one person as it means losing his/ her professional role to him/her (Polonský \& Matis, 2004), worse social status and limited privileges. On the other hand, another person who has a lot of interests and a rich family life can look forward to the retirement and to the activities that they have planned over a long period of time (Křivohlavý, 2011; Janiš, Jr. \& Skopalová, 2016). Certain features of an ageing personality, especially optimism, help to adapt to the conditions of the old age. A retired person symbolically leaves society for their privacy. The retirement affects all aspects of personality, as each person loses (depending on their preferences) more or less from the focus of one important sphere of their productive being, which in turn 
affects his or her future course of life, further experience, reasoning and behavior. At this stage, the focus should be redirected in such a way that retirement life corresponds with the individual's philosophy of life. It is also necessary to strengthen his/her perspective of the world towards the integrity of their personality (Erikson, 2002). Changes in social status directly affect their self-image, the awareness of one's own value as a person and as a member of society (Cimický \& Sámková, 2018).

In the macro-view, the generation of older people at the age of retirement can be regarded as a specific social minority in relation to society, characterized by a higher economic dependence on society and a limited possibility to intervene into its actions.

The peculiarities of the ageing population in Slovakia pose serious challenges to social and educational policy in Slovakia and they are listed in the following:

a) In a few years' time, Slovakia will become the country with the oldest population in the European Union (according to the Slovak Academy of Sciences). In terms of demographic development, the Slovak population is ageing at a faster pace than populations in neighboring countries. By improving living conditions, life expectancy in most countries of the world has recently extended, and in Slovakia, this period stands for almost ten years (Wang et al., 2018). According to research, life expectancy has also extended in Slovakia, e.g., between 1970 and 2010, for men, life expectancy increased from 66.8 to 71.6 years of age and for women from 73.2 to 79.1 years of age (note: in this respect, the development in the Slovak Republic is more similar to the Hungarian than the Czech one). In particular, the country's demographic development needs to be addressed as the minority will gradually become the majority. It is necessary to take into account various factors, e.g., in 2009 Slovakia had $16.8 \%$ of the population at the age 60 years or more and in 2050 this figure in Slovakia will approach $36 \%$ (according to UN estimates). According to various estimates, by 2060, the number of the retired people in Slovakia will double (according to the Slovak Academy of Sciences, 2014). Already in 2035, there will be twice as many people over 80 in Slovakia (Vaňo, 2015a). The turning of people born in the late 1940s and in the 50s of the last century into old age will result into the fact that the society will age fairly dynamically. However, ageing will occur not only from below (i.e. low fertility and the birth rate) and from above (i.e. life expectancy), but also from the middle (i.e. the shift of numerous generations from the 50s and 70s into older age pyramid) (Vaňo, 2015b).

b) There are several questions dealing with the quality of life of retired people. Despite the long-term predictions of the development of Slovak society, real Slovak society is not sufficiently (mentally and economically) prepared for such a rate of increasing the share of senior citizens in the population. 2012 was dedicated to the issue of active ageing and solidarity between generations in the EU (ERAS 2012). It was supposed to alert society and decision-makers that with demographic change, it was crucial to reflect on the position of senior citizens in society and on their ability to make use of their knowledge, work and human potential. Despite the fact that the standard of living of Europe's population is rising, the findings in 
terms of maintaining the quality of life during the old age are less positive (Hasa, 2019). Nearly half of the population of Europe is afraid of retirement and of life during retirement. However, the worst prospects are expected by employees from Eastern Europe (European Pension Survey, 2017). Up to 60 \% of Slovaks consider the low standard of living the most serious problem of the elderly, which is followed by a weakened health condition. Similar results are confirmed by the Institute for Public Affairs (IVO), which has been focusing on the position of senior citizens in Slovak society since 2012, as well as on issues of active ageing, participation and discrimination of senior citizens and public perception of these problems. (The research team has set the goal of bringing new insights into the life situation of senior citizens and their experience with discrimination, as well as with their degree of participation in different areas of society; to recognize opinions on the status and rights of senior citizens; to point out age stereotypes; to analyze the readiness of the public and older people to accept the active ageing model and to contribute to the cultivation of the public debate on the rights of older people and to offer knowledge useful in public policy). Slovakia responded to the European Year for Active Ageing (2012) by approving the National Active Ageing Program for 2014-2020. In January 2014, the Council of the Government of the Slovak Republic was re-constituted for the rights of senior citizens and for adapting public policies for the benefit of the ageing population. A. Zaidi et al. (based at the European Center for Social Policy and Research in Vienna) have developed a relatively detailed Index of Active Ageing, which should help to cover several aspects of active ageing and should measure the activities of senior citizens in their forms and experience based on different socio-demographic characteristics and in a broader context.

c) Slovakia is seen as one of more conservative countries in Europe, yet the influence of individualistic Western culture increasingly contributes to the isolation of senior citizens. Life in the globalized world of advanced societies of the $21^{\text {st }}$ century has caused a reduction in social contacts, a weakening of social ties and it has contributed to greater isolation of its members. Independence, uniqueness and autonomy - these are three qualities that Western society places great emphasis on and which promote individuality (Marcus \& Kitayama, 1991). In the educational process of children and of the youth, there are strategies that are employed in order to promote the awareness of each person as a self-confident, original being who, above all, values their own freedom and is less willing to make compromises and to adapt to other members of the group. According to Marcus and Kitayama (1991), it is the exaggerated emphasis on human uniqueness that causes the loneliness of people at present. Withdrawing an individual into their world in a priority-oriented approach, relying on themselves (without sharing and opening up to their family, peer group at school and community) significantly contributes to the individualization while contributing to weakening cohesion in the current globalization of "tested" families and therefore, it contributes to the increase in divorce rate. 
d) Increasing the share of lone senior citizens in society. Loneliness presents a problem not only for people who grow old in the $21^{\text {st }}$ century. According to research conducted by American sociologists, there is an increased amount of people who do not have any close friends. An increase in single parents, single parent families can be observed as well (Napora, 2013a). Naturally, there are economic and social consequences that are related to this aspect. One-adult households are at greater risk of poverty, not to mention old people whose pension is their sole income. Pope John Paul II. (2003) identified loneliness as the greatest threat for modern people. Young families are increasingly unwilling to integrate lone parents into their families and the caring function is taken over by the state but even the private and non-profit sector is not enough to participate. As a result, there are "waiting" advisors published on official websites of social services. Loneliness, together with a feeling of redundancy, significantly contributes to the increase in morbidity and suicidal behavior, the incidence of which increases with age. We do not even have to quote the classic (e.g., Jaspers) who claims that in essence, a lonely person can never be blissful. We assume that the topic of death appears more rarely in the thoughts of active senior citizens than in the thoughts and reflections of introverted and apathetic ones (Strieženec, 1996). Research indicates that with senior citizens who practice religion (more than $70 \%$ of the population in Slovakia), there is a substantial decrease in a possibility of voluntary termination of life despite difficult living conditions (see Drotárová, Antoničová, \& Drotárová, 2003).

e) The technology and informatisation of society weakens the ties between parents and children. (Lorenz, 1973) and the atmosphere of trust dies out. Family members spend less time communicating, they are no longer living together; rather, they live side by side. While the younger generation to some extent compensates for the lack of physical and social contact - direct social interaction, functioning in the virtual world and sharing of feelings, they often solve personal problems with completely unknown people in online discussion forums. The unpreparedness of most senior citizens to work with new technologies, in contact with which they feel as "generation after their prime" presents another disadvantage. Senior citizens do not have enough opportunities to share and fulfill the feeling of belonging to the family; therefore, they are looking for other places where they can find partners for conversations.

At this point, we can observe a great risk as the credibility of senior citizens (many of them returning to childhood with higher retirement age) who, by trusting strangers outside the family, can seriously endanger themselves.

f) Weakening of the position of senior citizens in families, a decrease in intergenerational solidarity. The family is the most important social institution which influences the quality of life of senior citizens. The situation of a senior citizen is directly related to the conditions of the family (Ziemska, 1980) in which they live: the quality, frequency and intensity (i.e. cordiality) of relationships. At present, for several reasons, the frequency of face-to-face family meetings with the participation of elderly parents 
is on decrease (Napora, 2013a). Even in the era of socialism, families, especially in the countryside had a much closer contact with senior citizens. There were not any serious decisions taken without consulting the eldest family members. In solving problems with the participation of the elderly who carefully deliberated and often tamed passions, they facilitated the resolution of internal conflicts and serious family crises. At present, they are often ignored in this process. For a long time, senior citizens dominated the ceremonial calendar (Matoušek, 1999) e.g., during celebrations of anniversaries, seasonal work, and leisure time which was spent together. The elimination of presence of senior citizens from these activities undermines the continuity of transgenerational transmission, as traditions that have consolidated the community for centuries and have fostered common awareness are not respected (Cabanová, 2006). Even the process of sharing an event such as passing away acted as a unifying motive for family life. The open demonstration of respect and dignity in dealing with the sick was of prime importance together with respecting their personality, associating their honor, adhering to their recommendations, respecting the decisions at the time of their "weakness", and later, preserving their memory.

g) A significant reduction in the number of multi-generation families. A multigenerational family, rich in ties and opportunities for contacts provides a form of support for its members, a sense of belonging, even if one parent is absent from the family for a long time, even in a matrifocal family where the absence of a father is permanent (Skupnik, 2010). In a long term, grandparents are also able to substitute the absence of parents in the family (Napora, 2013a). E.g. grandfather in an incomplete family presents a model of male behavior to grandchildren that children would not observe in a family without father. The relationship of grandparents and grandchildren is of particular importance, which is mutually enriching and it unites a multi-generation family. Grandparents reflect themselves in their grandchildren and they can devote time which they did not have for their own children when they were in productive age (Napora, 2013b). After the eventual loss of this natural contact, the impossibility of restoring social ties with grandchildren, the ageing person loses the foothold and often the meaning of life as well. The meaning of human life is associated with the need for usefulness in family and in society, and the feeling of uselessness and loneliness is often reinforced with doubts about oneself.

\section{Death as a taboo}

The ageing process must be accepted internally. According to Jung (1995), being unable to grow old is as embarrassing as the inability to abandon the age of childhood at the age of majority. Thus, the ability to accept the necessary is a part of the maturity of ageing. As Augustine (1997, p. 102) notes, the ending of being is the final and inevitable culmination of every human existence as "creatures arise and perish ... not all of them 
age, but all perish".

In the societies of the past, the notion of mortality appeared to be something personal and intimate. Social phenomena such as revolts, revolutions, wars, natural disasters, various diseases, low levels of health care and other life-threats contributed to the fact that death threats and death expectations were ubiquitous and were an integral part of everyday life in families of that time (Možný, 2008). These factors strengthened the acceptance of death as a matter of course, as a standard component, as an accepted necessity. The expectation of death was a part of the awareness of contemporary societies, which even intensified with the spread of Christianity ("a memento mori - remember death") and strengthened in the consciousness of man along with his/her ageing. In European community for many centuries, since the Middle Ages onwards, the value of an optimal, Christian death has resonated (Dupkala, 2011). In the past, ceremonies related to the end of life - ceremonial ritualization belonged to the main identifying factors of the spiritual level of the community that concluded the existence of one being.

The end of being could be perceived differently in the awareness of the community; it was the subject of folklore and fairy tales. It is sufficient to read thematic-oriented fairy tales by Pavel Dobšinský, which have a touch of horror storytelling for listeners/readers at present and it can be seen how much distance in the past people took on various aspects of the end of human existence.

With the development of more complex social relationships, the view of the end of human life has gradually changed or it has been cultivated, respectively (note: the question is whether it was for the benefit of a dying person or for loved ones). From the perspective of various disciplines, the end of human life is defined in various ways, such as:

- In Christianity, the finality of life was a punishment for the original sin (Augustine, 1997). In this situation, death concerned only physical side, not the spiritual one (i.e. soul), but rather, it was its liberation. In a more recent religious approach, death is understood as the definitive "breakup of the principle of life (soul) with the body" (Sokol, 2010, p. 332).

- In philosophy, the issue of death and its acceptance has been analyzed for a long time from various perspectives since its inception. It is specifically dealt with in thanatology, which a branch of science dealing with the issues of the process of dying and death. At this point, on the one hand, we can see a confident view of the phenomenon of dignified death as a fundamental right of a free man among Greek philosophers, such as Socrates (note: for Socrates, death did not matter. He did not escape, although he had learnt from his disciples that he would be sentenced to death as he believed that punishment on the body could not hurt his soul). The idea can be found in Epicurus (1989), as a manifestation of free will of a man, despised by death to death as the good, which can be observed in Cicero (2009).

- In modern history, it is A. Schopenhauer who claims that a man goes inexorably into the face of death. In later stages, it can be seen in discussions about the right of man and the loss of this right to exist, especially with philosophers of the $19^{\text {th }}$ and $20^{\text {th }}$ centuries dealing with this issue (they were strongly influenced by Protestantism or Reformism). 
Both M. Heidegger and S. Kierkegaard claimed that existence is the personal core of a man whose expansive "I" is heading towards their own death. K. Jaspers considers death a borderline situation that cannot be avoided; we enter it as a whole. In the case of Jaspers' existentialism, the theory of borderline situations prevails. Jaspers was of opinion that the true meaning of being was revealed to a man only during deep shocks such as illness, death, irreparable guilt, anxiety and the like.

It is at these moments that the "decryption" takes place in which one frees himself/herself from the burden of worries of their daily life. Man reveals the world in the depths of his/ her intimate existence, his/her true experience of God (i.e. the transcendent). In contrast with previous philosophical trends, the central issues and methods of existentialism have become the borderline, escalated life situations of man - death, guilt, suffering, loneliness and anxiety (Šlosiar, 2002).

According to existentialists, anxiety is a way of possible looking at oneself, it is a selfreflection of human freedom, it is what a person reaches if they want to "find" and not "lose" themselves if they want to be themselves. They are also what they voluntarily get rid of in cowardice in alternative, non-authentic forms of life (Šlosiar, 2002). When we enter it with eyes opened, we become more ourselves (Störig, 1993). This is evident in Levinas and Landsberg (Dupkala, 2011), but especially in seemingly pessimistic vision by Sartre which stems from the existential principle that he formulated: "I have always realized that I had no right to exist ...... the only certainty that a human being has is the movement towards death". Generally, the questions of death and the finality of being are a timeless concept. The end of life is the nature of every organism; it is a negation and a denial of each individual. From philosophical point of view, which is seen as a state of non-existence, respectively, it is the end of open being and the completion of life, or as a transition of being to non-being. Thus, death is inevitable, it is the only certainty in life of the individual and of the group, and it is a universal component of all cultures across time and space (Jakubovská, 2016, p. 109).

- Psychological aspects. From the ontogenetic perspective, both ageing and old age processes are a natural part of the human life cycle and death presents the culmination and victory of involutional forces. Říčan (2004) follows this idea by stating that one is aware of his/her existence and by knowing in advance about death, this awareness profoundly affects their behavior, feelings and thinking. According to Jung (1995), only the person who accepts their finality, i.e. understands death even as a goal of life and as a certain fulfillment. In Erikson's theory (2002), the outcome of good life is, at the eighth stage, an "optimal" old age manifested by integrity. Achieving a state of integrity is manifested by accepting one's life as a whole and by understanding its meaning.

- Biological aspects. The most significant identification of the end of human being can be performed on the basis of diagnostics of demonstrable parameters of the absence of life, which are external manifestations of "not" functioning of human 
organism. This criterion is based on a biological and medical standpoint, which characterizes death as a cessation of activities, the absence of manifestations of vital functions and the loss of all brain functions and this specification is also employed in law-making (Michalco, 2019).

By definition, the end of human life can be characterized in various dimensions and it is also possible to affect the substance; however, the question is: What does death mean in terms of values of human life? At present, scientific literature is a frequent issue of the target and instrumental values of human life and of good and evil. By tabooing the issue of death, this phenomenon has recently seemed to be excluded from the axiological system. Taboos are not moral or religious principles, they themselves present a form of a ban (Freud, 1997, p. 29). The avoidance of the phenomenon of death in modern societies has contributed to the fact that leaving life is a mystery, discussed with fear, almost as a taboo of a "sacred shyness" (Freud, 1997).

Leaving life always presents an extremely difficult situation not only for the extinct existence, but also for its surroundings. At this time, it is essential to manifest certain form of contact, interest and understanding to contact persons. Fear is natural - even gods and demigods feared death (e.g. The Epic of Gilgamesh, The Iliad and The Odyssey); as a result, it is necessary to overcome this fear, to attain the state of reconciliation and forgiveness, to follow an optimal death (Dupkala, 2011). In every culture, there is a mechanism for the cultivation this fear of death and to make it bearable and rational. As Jung (1995) notes In Confinio Mortis (As Death Nears) in the evening of a long and eventful life, the vision broadens itself out into unsuspected vistas. Such a man no longer lives in the everyday world and in the peripeteia of personal relationships, but in the sight of many aeons.

\section{Discussion}

What does the reality of being imply for pedagogical sciences? Both ageing and retirement are an integral part of the eternal cycle of being. For this reason, in the current understanding of European culture, the "displacement" of these topics in life, in school education, and in culture is generally inappropriate (Petríková, 2019); as e.g., the artistically presented end of human life "returns children to life in its holistic understanding". In the conditions of the Slovak Republic, these are mainly changes in the following areas:

a) School policy: strengthening and an appropriate implementation of the issue in the content of school education at all levels of formal education. This process should take place in the context of linking life and school as an institution whose origin and mission are related to preparing children and young people for life (of which all phases of human life are an integral part), also in the perspective of presentday demographic trends. At present, the topic of the model of family with senior citizens is included in school education only marginally, the issue of ageing and the end of human life is completely absent from the curriculum of school education. 
In the concept of education towards partnership life and parenthood, this issue is displaced and the same approach, in the form of "avoiding this hot topic" has been manifested in minimizing the issue of the end of human life in the contents and forms of formal education, including in the subjects of ethics, citizenship and religious education where this issue properly belongs. This implies the necessity of the innovation of the content of education, the appropriate implementation of the topic, which should be sensitively introduced on the basis of the age of the pupil. The issues of human coexistence are important: topics about grandparents, about families with older people, the status of senior citizens in society, relationship with and protection of senior citizens, ethical issues of being and coexistence, bioethical issues of ageing, and natural death, the issue of euthanasia, etc.

b) Preparing future elementary and secondary school teachers for having qualified discussions with pupils on such challenging topics (this aspects is also related to the systematic training of teachers of courses in ethics, citizenship and religious education and subjects of primary and secondary schools, as well as the innovation of university study fields the subjects of this focus).

New challenges are also related to initiating the public debate on ageing and on the end of human life from various perspectives. There is a necessity of modification of social policy of the Slovak Republic which is based on the elaboration of the National Active Ageing Program for 2014-2020 and its projection into specific measurable steps (or goals) for the benefit of older people.

\section{Conclusion}

Within European culture, ageing dominated by beauty, youth, competition and performance is complex (none of the above mentioned expressions can be marked as frequent in the dictionary of senior citizens).

It is also unpopular to talk about ageing in the countries of the Eastern bloc primarily for other reasons, mainly due to the perception of ageing, which is seen as a period of "dependence on others". In the case of post-socialist countries, the "dependence on others" fully describes the economic dependence on children and the thin border between health and disease/poverty. In these countries, people are afraid of ageing for economic deprivation (it is the generation that gave away their children and no one led them to save for old age in the era of socialism, for health care was free). The third reason is that the natural outcome of ageing is death, which has been completely displaced from everyday life and the fear of the unknown is natural.

Nevertheless, old age can be considered a stage in life that can be experienced very positively and pleasantly, if we are able to accept it and take it as it is - then, ageing can also become successful. It is up to us whether it is death with a full stop or with a question mark. Ageing, however, poses ethical, medical, sociological and socio-educational questions for experts. The focus of both professional and public debate should have a deeper philosophical, educational, political and socio-economic dimension. However, this discussion 
will only make sense if it results into specific measures for the benefit of senior citizens. In addition to greater support of families that care for senior citizens, trends in society should induce new awareness-raising tasks, e.g., how to influence young people in a more effective way - with the aim to change attitudes and relation towards senior citizens. With the statement "what you see in one person can be reflected in you" in education of young generation for empathy and understanding, we prepare a better old age for them.

\section{References}

Adler, A. (1998). O zmysle života. Bratislava: Iris.

Atkinson, R. L. et al. (2003). Psychologie. Praha: Portál.

Augustín, A. (1997). Vyznania. Bratislava: Lúč.

Bakošová, Z. (2005). Sociálna pedagogika ako životná pomoc. Bratislava: Filozofická fakulta, Univerzita Komenského v Bratislave.

Baláž, V. et al. (2013). Stratégia aktívneho starnutia: podkladová štúdia. Retrieved from https://www.ia.gov.sk/cv/images/projekty/strategiaaktivnehostarnutia/Strategia_ aktivneho_starnutia_podkladova_studia.pdf

Barát, A. (2012). Na Slovensku sú ludia starí a diskriminovaní už po štyridsat́pät'ke. Retrieved April 2, 2012, from https://spravy.pravda.sk/domace/clanok/173896-naslovensku-su-ludia-stari-a-diskriminovani-uz-po-styridsatpaetke/

Bilasová, V. (2011). Človek na ceste sebapoznávania, sebahodnotenia a sebaukončovania. In O zmysle života. Beograd: Academia of Serbian Ortodox Church.

Bratská, M. (2001). Zisky a straty v zátažových situáciách alebo príprava na život. Psychofórum: bulletin Slovenskej psychologickej spoločnosti pri SAV, 1(2), 40.

Cabanová, V. (2006). Kontext rodiny a spoločnosti v čase globalizácie, alebo potrebujeme zachovat' tradičnú rodinu?. Rodina a škola, 54(3), 12.

Cabanová, V. (2007). Antiprejudicial education in the information society. Communications - Scientific Letters of the University of Žilina, 9(2), 45.

Cabanová, V. (2012). Problémy s inakostou - sociálne predsudky v stredoeurópskych spoločnostiach 21. storočia. In Akční pole sociální práce (pp. 11-18). Brno: Paido. 
Cabanová, V., \& Polonský, D. (2019). Rozvoj sociálnej pedagogiky v regióne severozápadného Slovenska. In Socialia. Banská Bystrica: Pedagogická fakulta, Univerzita Mateja Bela v Banskej Bystrici.

Camus, A. (1981). Eseje. Warszawa: Państwowy Instytut Wydawniczy.

Camus, A. (1993). Mýtus o Sizyfovi. Bratislava: Slovenský spisovatel'.

Cicero, M. T. (2009). O pohŕdaní smrtou. In Tuskulské hovory. Bratislava: Vydavatel'stvo Spolku slovenských spisovatel'ov.

Cimický, J., \& Sámková, J. (2018). Stáří jako fenomén. Retrieved February 19, 2018, from https://www.i60.cz/clanek/detail/19096/stari-jako-fenomen

Dončevová, S. (2017). Rodina a tolerancia inakosti. In Z. Bakošová (Ed.), Rodina, tolerancia inakosti a kvalita života detí a mládeže (pp. 79-84). Bratislava: Univerzita Komenského $\checkmark$ Bratislave.

Drotárová, E., Antoničová, I., \& Drotárová, L. (2003). Religiozita a zvládanie stresu. In Pravoslávny teologický zborník 26/11 (pp. 231-236). Prešov: Pravoslávna bohoslovecká fakulta, Prešovská univerzita.

Dupkala, R. (2011). Problém smrti v kontextoch "eutélie" a "fenomenológie zmyslu" života. In O zmysle života (pp. 141-155). Beograd: Academia of Serbian Ortodox Church.

Epikuros (1989). O št́astnom živote. Bratislava: Pravda.

Erikson, H. E. (2002). Dětství a společnost. Praha: Argo.

Freud, S. (1997). Totem a tabu. Praha: Psychoanalytické nakladatelství.

Fürst, M. (1997). Psychologie. Olomouc: Votobia.

Gabrižová, Z. (2017). Aktívne starnutie: Nevyužitý potenciál starších ludí. Retrieved from https://euractiv.sk/section/veda-a-inovacie/linksdossier/aktivne-starnutie-nevyuzitypotencial-starsich-ludi/

Hasa, P. (2019). Analýza sociálno-ekonomických aspektov kvality života seniorov na Slovensku. Retrieved from https://www.prohuman.sk/print/socialna-praca/analyzasocialno-ekonomickych-aspektov-kvality-zivota-seniorov-na-slovensku

Haškovcová, H. (1989). Fenomén stáří. Praha: Panorama. 
Helus, Z. (2003). Psychologie. Praha: Fortuna.

Hofmanová, V. (2019). Finty, které oddaluji stárnutí. Retrieved from https://www.i60.cz/ clanek/detail/23854/finty-ktere-oddaluji-starnuti

IVO. Inštitút pre verejné otázky. (2012). Starší vek a l'udské práva: silnejšia participácia, menej diskriminácie. Retrieved from http://www.ivo.sk/6763/sk/aktuality/starsi-vek-aludske-prava-silnejsia-participacia-menej-diskriminacie

Jakubovská, K. (2016). Ritualizácia ako prostriedok utvárania kolektívneho obrazu smrti. In K. Gabašová et al., (De)tabuizácia smrti vo filozoficko-antropologickom diskurze (pp. 109-126). Nitra: Univerzita Konštantína Filozofa v Nitre.

Ján Pavol II. (2003). Posolstvo svätého otca mládeži sveta pri príležitosti XVIII. svetového dňa mládeže. Retrieved April 13, 2003, from https://www.kbs.sk/obsah/sekcia/h/ dokumenty-a-vyhlasenia/p/dokumenty-papezov/c/posolstvo-mladezi-18

Janiš, K., Jr., \& Skopalová, J. (2016). Volný čas seniorů. Praha: Grada.

Jung, C. G. (1995). Človek a duše. Praha: Academia.

Jurovský, A. (1946). Súlad v rodinnom živote. Martin: Neografia.

Kierkegaard, S. (1993). Bázeň a chvění. Praha: Svoboda-Libertas.

Kierkegaard, S. (1994). Svůdcův deník. Bratislava: Chronos.

Kollárik, T. (1993). Sociálna psychológia. Bratislava: SPN.

Koval, Š. (2001). Týranie starých ludí. Košice: Posit.

Křivohlavý, J. (2011). Stárnutí z pohledu pozitivní psychologie. Praha: Grada.

Kübler-Ross, E. (1990). Interviews mit Sterbenden. Gütersloh: Gütersloher Verl.-Haus Mohn.

Langmeier, J., \& Krejčířová, D. (1998). Vývojová psychologie. Praha: Grada.

Langmeier, J., \& Krejčířová, D. (2006). Vývojová psychologie (2nd ed.). Praha: Grada.

Lorenz, K. (1973). Osm smrtelných hříchů. Český Tešín: Reprint. 
Marcus, H., \& Kitayama, S. (1991). Culture and the self: Implications for cognition, emotion, and motivation. Psychological Review, 98(2), 224-253.

Matoušek, O. (1999). Rodina jako instituce a vztahová sít. Praha: SLON.

Matoušek, O. et al. (2007). Základy sociální práce. Praha: Portál.

Michalco, D. (2019). Axiologická dimenzia fenoménu smrti vo filozofickej reflexii (diploma thesis). Žilina: Žilinská univerzita v Žilině, Fakulta humanitných vied.

Možný, I. (2008). Rodina a společnost (2 ${ }^{\text {nd }}$ ed.). Praha: SLON.

Nakonečný, M. (1999). Sociální psychologie. Praha: Academia.

Napora, E. (2013a). Komunikacja matek w parach z córką i synem w rodzinach o różnej strukturze [Communication of mothers in dyads with daughters and sons in families of different structure]. Częstochowa: Wydawnictwo Akademii im. Jana Długosza w Częstochowie.

Napora, E. (2013b). Psychological Image of Seniors in Poland. In. P. Escuder-Mollón, \& S. Cabedo (Eds.), Education and Quality of life of Senior Citizens (pp. 62-66). Castelló de la Plana: Universitat Jaume I.

OECD/European Observatory on Health Systems and Policies. (2017). Slovensko: Zdravotný Profil Krajiny 2017. doi: 10.1787/9789264285408-sk

Palát, M. (2003). Ageizmus a súčasnost'. Revue medicíny v praxi, 1(4), 33.

Petríková, M. (2019). Metamorfózy rozprávky o smrti. Banská Bystrica: Pedagogická fakulta, Univerzita Mateja Bela v Banskej Bystrici.

Polonský, D., \& Matis, J. (2004). Vybrané problémy zo sociológie výchovy. Liptovský Mikuláš: LIA.

Rokusek, C. (2013). Elder Suicide: A Case for Interprofessional. Primary Intervention. (Lecture for students, Faculty of Humanities, University of Žilina in Žilina, 10 November 2013).

Říčan, P. (2004). Cesta životem. Praha: Portál.

Sartre, J. P. (1997). Existencializmus je humanizmus. Bratislava: Slovenský spisovatel'.

Skupnik, J. (2010). Antropologie príbuzenství. Praha: SLON. 
Sokol, J. (2010). Malá filosofie člověka a Slovník filosofických pojmů (6 $6^{\text {th }}$ ed.). Praha: Vyšehrad.

Soukup, V. (2016). Smrt jako biologická konstanta a kulturní konstrukce: Příspěvek k antropologii smrti. In K. Gabašová et al., (De)tabuizácia smrti vo filozofickoantropologickom diskurze (pp. 81-108). Nitra: Univerzita Konštantína Filozofa v Nitre.

Steindl, R. (2000). O smrti. Bratislava: Iris.

Störig, H. J. (1993). Malé dějiny filozofie. Praha: Zvon.

Strieženec, Š. (1996). Slovník sociálneho pracovníka. Trnava: AD.

Šlosiar, J. (2002). Od antropologizmu k filozofickej antropológii. Bratislava: Iris.

Šmarda, J. et al. (2007). Biologie pro psychology a pedagogy. Praha: Portál.

Šprocha, B. (2015a). Počet Slovákov stúpa, obyvatel'stvo však starne: je nás najviac za uplynulých 10 rokov. Retrieved from www.novycas.sk

Šprocha, B. (2015b). Vekové zloženie obyvatel'stva v Slovenskej republike a v krajoch a jeho prognóza do roku 2030. Slovak Statistics and Demography, 3(25), 7-21.

Vaňo, B. (2015a). Editoriál. Slovak Statistics and Demography, 3(25), 1-2.

Vaňo, B. (2015b). Slovensko bude mat' v roku 2035 dvojnásobok ludí nad 80 rokov. Retrieved from https://www.postoj.sk/4475/slovensko-bude-mat-v-roku-2035dvojnasobok-ludi-nad-80-rokov

Vágnerová, M. (2000). Vývojová psychologie. Praha: Portál.

Wang, H. et al. (2018). Ĺudia získali šancu na dálšie desat'ročie života. Retrieved from https://www.aktuality.sk/clanok/220105/ludia-celosvetovo-ziskali-od-roku-1970-sancuna-dalsie-desatrocie-zivota/

Witte, E. H. (1989). Sozialpsychologie. München: Psychologie Verlags Union.

Zaidi, A., \& Stanton, D. (2015). Active Ageing Index 2014: Analytical Report. Retrieved October 12, 2018, from https://statswiki.unece.org/display/AAl/International +Seminar?preview=/100303133/112394517/AAI\%20Report\%20LOW\%2ORES.PDF

Ziemska, M. (1980). Rodina a osobnost'. Bratislava: Smena. 


\section{Author}

doc. PaedDr. Vlasta Cabanová, PhD.

Faculty of Humanities, University of Žilina

Department of Pedagogical Studies

Univerzitná 8215/1, 01026 Žilina, Slovak Republic

vlasta.cabanova@fhv.uniza.sk 